\title{
ТОЛЕРАНТНІСТЬ ЯК ОСОБИСТІСНА ЛІДЕРСЬКА ЯКІСТЬ МАЙБУТНІХ ВИКЛАДАЧІВ ЗАКЛАДІВ ВИЩОЇ ОСВІТИ
}

У статті охарактеризовано дефініції «толерантність», «лідер», «лідерство», «лідерські якості», «лідерська позиція» викладача закладу вищої освіти, розкрито принципи толерантності, схарактеризовано структуру толерантності як особистісної лідерської якості майбутніх викладачів закладів вищої освіти, щчо поєднує три взаємопов'язаних складники: когнітивний (усвідомлення ідей толерантності; відповідність принципам загальнолюдської моралі; повага, сприйняття та розуміння багатого розмаїття культур нашого світу, форм самовиявлення людської особистості; «законослухняність», підпорядкування законам, традиціям і звичаям), емочійно-ціннісний (стійкі почуття лідера до об'єктів, до процесу толерантної взаємодії з ними; емоційно-ціннісне позитивне ставлення до людей, інших точок зору, етнічних питань, зв'язків, почуттів; емочійна врівноваженість, стійкість до зовнішніх чинників, позитивне сприйняття критики; взаєморозуміння, компроміс, терпимість, повага до кожного члена колективу $і$ суспільства), діяльнісно-комунікативний (схильність до певного типу сочіальної поведінки, основою якої є розуміння, співпрачя; загальна скерованість діяльності лідера і колективу на об 'єкти і явища сочіальної значущості; взаємодія лідера з колективом на рівні діалогу, співробітництва, опіки; уміння працювати з іншим на результат, попереджати і розв 'язувати конфлікти, досягати компромісів).

Підкреслено, ще саме толерантність є основою віротерпимості і миролюбства, запобігання будь-яким видам екстремізму, щзо мають для багатоначіональної й багатоконфесійної України особливу значущість. Толерантність - один з головних принципів не тільки взаємовідносин між людьми, але і ефективного лідерства - не стільки соціального, стільки особистісного феномену: лідер може бути сильною особистістю, але без сформованих навичок міжособистісної взаємодії на засадах визнання иінності іншого (тобто, по суті, на засадах толерантності) його потенціал може залишитись нереалізованим.

Аргументовано позииію професійно компетентного педагога вищої школи, який сприймається у соиіумі не тільки як взірець і лідер, але і як особистість, щзо вміє налагоджувати контакти з усіма учасниками освітнього процесу, незважаючи на вік, національність, сочіальний стан, належність до різних культур тощьо; тим самим стверджуючи власну толерантну позицію.

Ключові слова: толерантність, гуманістичні иінності, демократизація суспільних процесів, лідер, лідерські якості, компоненти толерантності як особистісної лідерської якості. 
Lidiya CHEREDNYK, orcid.org/0000-0002-1006-1363

Candidate of Pedagogical Sciences, Assistant at the Department of Pedagogy of the Faculty of Humanities and Pedagogy National University of Life and Environmental Sciences of Ukraine (Kyiv, Ukraine) lidiya2772@i.ua

\section{Nadiia DIRA, \\ Assistant at the Department of Pedagogy of the Faculty of Humanities and Pedagogy National University of Life and Environmental Sciences of Ukraine (Kyiv, Ukraine) dira.nadija90@gmail.com}

\section{TOLERANCE AS A PERSONAL LEADERSHIP QUALITY OF FUTURE TEACHERS OF HIGHER EDUCATION INSTITUTIONS}

The article describes the definitions of "tolerance", "leader", "leadership", "leadership qualities", "leadership position" of a teacher of higher education. The principles of tolerance are revealed, the structure of tolerance as a personal leadership quality of future teachers of higher education institutions that is combined of the three interrelated components: cognitive (awareness of the ideas of tolerance; compliance with the principles of universal morality; respect, perception and understanding of the rich diversity of cultures of our world, forms of self-expression of the human person; "obedience to the law", obedience to laws, traditions and customs), emotional value (stable feelings of the leader to objects, to the process of tolerant interaction with them; emotional and value positive attitude to people, other points of view, ethnic issues, connections, feelings; emotional balance, resistance to external factors, positive perception of criticism; mutual understanding, compromise, tolerance, respect for each member of the team and society), activitycommunicative (tendency to a certain type of social behavior, the basis of which is understanding, cooperation; general orientation of the leader and the team on objects and phenomena of social significance; interaction of the leader with the team at the level of dialogue, cooperation, guardianship; ability to work with others and resolve conflicts, reach compromises).

It is emphasized that tolerance is the basis of religious tolerance and peace, prevention of any kind of extremism, which are of special importance for a multinational and multi-religious Ukraine. Tolerance is one of the main principles not only of relationships between people, but also of effective leadership - not so much a social, so a personal phenomenon: a leader can be a strong personality, but without established skills of interpersonal interaction based on recognizing the value of another (i.e., essentially tolerance) its potential may remain unrealized.

Argued position professionally competent teacher of high school, which is perceived in society, not only as a model and leader but also as a person who can establish contacts with all parties to the educational process, regardless of age, nationality, social status, belonging to different cultures, etc; thereby asserting his tolerant position.

Key words: tolerance, humanistic values, democratization of social processes, leader, leadership qualities, components of tolerance as a personal leadership quality.

Постановка проблеми. Суспільні процеси глобального світового масштабу, соціокультурні перетворення, продиктовані необхідністю формування нових соціально-економічних, соціально-культурних відносин, демократизація політичних процесів в Україні та світі, утвердження гуманістичних цінностей диктують вимоги до особистості, готової до участі в демократичному управлінні суспільством, виявленню лідерських якостей на засадах толерантності. Окреслені зміни зумовили трансформацію ціннісних пріоритетів, серед яких поняття «толерантність» розглядається як соціально важливе явище, норма життя у полікультурному, багатоконфесійному, інтернаціональному суспільному просторі. 3 одного боку, це - усвідомлення необхідності збереження неповторної особливості кожної особистості або певної суспільної групи, з іншого - толерантне ставлення до всього, що виходить межі їі звичного сприйняття, $€$ інакшим, відмінним від уже сформованого стереотипу. Саме толерантність $€$ основою віротерпимості і миролюбства, запобігання будьяким видам екстремізму, що мають для багатонаціональної й багатоконфесійної України особливу значущість. Це один 3 головних принципів не тільки взаємовідносин між людьми, але і ефективного лідерства - не стільки соціального, стільки особистісного феномену: лідер може бути сильною особистістю, але без сформованих навичок міжособистісної взаємодії на засадах визнання цінності іншого (тобто, по суті, на засадах толерантності) його потенціал може залишитись нереалізованим.

Сьогодення констатує суттєве зростання інтересу до проблеми формування лідерської позиції 
та лідерських якостей у майбутніх фахівців вищої школи. Це зумовлено низкою чинників, серед яких одним із визначальних $\epsilon$ світова тенденція переходу від індустріальної моделі розвитку до інформаційної, що викликає зміни у цілях, змісті, і відповідно, у функціях та завданнях діяльності сучасного педагога.

Саме окреслена зміна пріоритетів потребує від сучасного педагога вищої школи лідерських якостей, що забезпечують лідерство на гуманістичних i демократичних засадах, принципах толерантності, суб'єкт-суб'єктної взаємодії.

Тому проблема толерантності як особистісної лідерської якості майбутнього викладача вищої школи є полемічною, актуальною та потребує подальших досліджень.

Аналіз досліджень. У сучасних наукових розвідках проблема толерантності як особистісної якості майбутнього педагога та освітнього орієнтиру розглядалася різноаспектно: методологічні основи сучасної філософії освіти (В. Андрущенко, В. Кремень, В. Лутай, В. Огнев'юк та ін.); загальні питання педагогіки толерантності (М. Андреєв, О. Безкоровайна, О. Грива, Г. Коберник, Л. Москальова, Ю. Тодорцева та ін.); психолого-педагогічні засади формування педагогічної толерантності майбутніх педагогів (Т. Атрощенко, Н. Бирко, Т. Варенко, Ю. Гордієнко, А. Горянська, Ю. Ірхіна, Е. Кайкова, О. Кондратьєва, Р. Кострубань, I. Кривошапка Л. Мацюк, М. Мельничук, О. Руда, А. Скок, О. Столяренко, І. Сухопара та ін.).

Проблемам розвитку лідерських якостей у здобувачів вищої освіти присвятили свої дослідження Б. Головешко, А. Зоріна, А. Іващенко, Л. Кайдалова, В. Мороз, О. Пономарьов, О. Савельєва (загальні питання); І. Богданова, К. Демчук, Н. Мараховська, I. Савицька (у майбутніх педагогів); Р. Сопівник (у майбутніх фахівців агропромислової галузі); Л. Казанцева (у майбутніх лікарів); О. Левченко, О. Савельєва (у майбутніх менеджерів); Н. Бабкова-Пилипенко, Г. Чередніченко (у майбутніх економістів) та ін.

Мета статті - подати теоретичне обгрунтування толерантності як особистісної лідерської якості майбутнього викладача вищої школи та схарактеризувати їі структурні компоненти.

Виклад основного матеріалу. Процеси глобалізації, євроінтеграції та реформування сучасної освіти окреслюють рамки простору, побудованого на утвердженні людини як найбільшої соціальної цінності, управління та лідерства на засадах демократії, гуманізму, толерантності, й вимагають від педагога готовності до діалогу з соціумом шляхом встановлення відносин довіри, співпраці, компромісу, радості, товариськості, емпатії та психологічного комфорту.

Професійно компетентний педагог вищої школи, будучи взірцем і лідером, сприймається у соціумі як особистість, що вміє налагоджувати контакти $з$ усіма учасниками освітнього процесу, незважаючи на вік, національність, соціальний стан, належність до різних культур тощо; тим самим стверджуючи власну толерантну позицію.

Засадничі ідеї толерантності відображені в низці визнаних в Україні міжнародних документів (Декларація принципів толерантності (1995), Конвенція про права людини (1948), Конвенція про права дитини (1989)), Конституції України (1996) та наскрізною лінією проведені у Законах України «Про освіту» (2017), «Про вищу освіту» (2014), в нормативно-правових документах системи освіти України: Національній стратегії розвитку освіти в Україні на період до 2021 року (2013), Стратегії сталого розвитку «Україна-2020» (2015), Концепції розвитку педагогічної освіти (2018).

Зважаючи на сказане вище, метою сучасної освіти у вищій школі є вільний розвиток індивідуальних здібностей, мотивів, особистісних цінностей майбутнього фахівця (Г. Сиротенко та ін.). Окрім демонстрації важливих особистих професійних якостей, уміння генерувати та впроваджувати в освітній процес позитивні педагогічні ідеї, викладач вищої школи має виявляти високий рівень професійно-етичної, комунікативної, рефлексивної культури; розвивати особисту креативність, виступати лідером на засадах принципів толерантності, демонструвати своє персональне, особистісне і професійне зростання та компетентність у досягненні зазначених цілей (Г. Васянович, Л. Запара та ін.); активно залучати до своїх дій інших людей, впливаючи на них своєю впевненістю і переконливістю. У свою чергу, щоб стати лідером, необхідно володіти вмінням спілкуватися 3 різними людьми та проявляти ініціативу, демонструвати чуйність і увагу, емпатію та толерантність (К. Берд, Р. Сопівник, О. Тихомирова та ін.); розвивати комунікативні навички, володіти інструментами отримання інформації (Я. Кульбашна, О. Ткачук та ін.).

Толерантність як ціннісна складова входить до низки компетентностей, визначених національними стандартами кваліфікованого педагога в європейських країнах (Department, 2002).

Якщо узгодити принципи толерантності, розроблені міжнародними організаціями та поширені в країнах Європи, з напрацюваннями вітчизняних педагогів, то вимальовується досить чітка номен- 
клатура принципів та орієнтирів лідерської позиціі майбутнього викладача вищої школи: ненасильництва - настроєність на запобігання конфлікту, а у разі його виникнення розв'язання без застосування відкритого примусу; свободи - право на здійснення вибору позиції, аргументів, способів доведення та висловлювання думки; самостримання - уміння примусити себе вислухати іншого, прийняти його погляди, визнати аргументи, зберігати рівновагу; «законослухняність» - дотримання існуючих норм, правил, традицій, а не тиску сильнішого чи формальної більшості; сприйняття іншого - повага до різних проявів іншого. Усі ці складники можна об'єднати одним словом - толерантність, окреслюючи цю дефініцію як освітній орієнтир у процесі формування лідерських якостей майбутніх викладачів вищої школи.

Толерантність згідно 3 гуманістичним підходом розглядається як один $з$ принципів (система принципів) і розуміється як партнерство у спілкуванні, як суб'єкт-суб' єктна взаємодія (I. Бех, А. Петровський та ін.); як формування культури діалогу (М. Бахтін, В. Біблер та ін.); як формування установок толерантної свідомості (О. Асмолов, Г. Солдатова, Л. Шайгерова та ін.); як здатність індивіда без заперечення та протидії сприймати чужі думки, стиль життя, характер поведінки та інші особливості, що в сумі складає основу відмови від агресії (С. Бондирєва, Д. Колесов, А. Молчанова та ін.).

Поняття «толерантність» у психолого-педагогічній літературі тлумачиться у різних значеннях залежно від предмета дослідження та обраних дослідником підходів. Так, С. Братченко визначає низку підходів щодо розуміння сутності цього явища: гуманістичний, згідно з яким толерантність розглядається як прояв свідомого, осмисленого та відповідального вибору людини, ії власної позиції; особистісний, відповідно до якого психологічною основою толерантностієцінності,смислита особистісні установки; діалогічний, в основі якого лежить міжособистісна толерантність як особливий спосіб стосунків і міжособистісної взаємодії з іншим та міжособистісний діалог; диверсифікаційний, відповідно до якого зміст толерантності не зводиться до однієї властивості, а розглядається як складний, багатоаспектний та багатокомпонентний феномен; фасилітативний підхід розглядає толерантність як якість, що розвивається (Братченко, 2003).

За критерієм визначення толерантності як специфічної системи стабілізації особистості і іiі психологічної стійкості В. Ляпунова виокремлює: «толерантність до стресу», «толерантність у стресових ситуаціях» або «фрустрація» - готовність до «непередбачених робочих обставин» або до «роботи $з$ недоброзичливо налаштованими особами»; «толерантність до тривоги» і «толерантність до дискомфорту»; «афективна толерантність» або «толерантність до емоційного стресу»; «толерантність до фізичного навантаження», «толерантність до одноманітної, монотонної діяльності»; «толерантність до критики» та «толерантність до негативу»; «толерантність до слави» тощо (Ляпунова, 2016).

Аналіз наукових досліджень і публікацій 3 проблеми формування лідерства як особистісної якості педагога вищої школи засвідчив, що існують різні погляди щодо сутності цього поняття та підходи до його дослідження.

На думку А. Кузьмінського та В. Омеляненка, лідер (від англ. leader - той, який веде, керує) - це член колективу, який у важливих ситуаціях здатний помітно впливати на поведінку членів колективу, виявляти ініціативу у прийнятті рішень та діях, брати на себе відповідальність за діяльність колективу (Кузьмінський, Омеляненко, 2006:305). У свою чергу Д. Алфімов зазначає, що «ефективний лідер» - це особистість, яка має значний вплив на думку й поведінку членів групи та яка планує, організовує, контролює діяльність підлеглих задля розв'язання спільних завдань, передаючи їм своє бачення вирішення проблеми та наслідків такого рішення (Алфімов, 2010:50). Поряд з цим, синтезуючи поняття «лідер», «лідерство» 3 терміном «якість», дослідник пропонує таке визначення: лідерські якості особистості - це узагальнені властивості лідера створювати нове бачення розв'язання проблеми, успішно впливати на послідовників у напрямі досягнення групою або організацією цілей (Алфімов, 2010:50).

Так, відповідно до теорії лідерства (К. Берд, Г. Кунц, Р. Манн, Р. Стокділл, Р. Шток та ін.), лідер володіє як вродженими, так і набутими (у тому числі у процесі професійного зростання і самовдосконалення) рисами характеру, а також особливими здібностями до реалізації лідерства. Сучасні дослідження 3 проблем лідерства (П. Бейдер, С. Заккаро, К. Кемп та ін.) наполягають на відсутності вродженого набору якостей для реалізації лідерського потенціалу, але не заперечують існування певних рис, які, згідно даних досліджень, не $\epsilon$ вродженими та водночас входять до переліку «лідерських» якостей. Натомість мова йде не про конкретні «універсальні» риси, а про сформовані в суспільстві очікування щодо особистості лідера.

Серед компонентів лідерських якостей дослідники виокремлюють або ж толерантність як особистісну якість (А. Косінова, Н. Сушик та ін.) або 
складники, що тісно з нею пов'язані, характеризують іï: урівноваженість, емоційно-позитивне самопочуття, психологічна надійність (В. Татенко, В. Ягоднікова та ін.); доброзичливість, врівноваженість (К. Берд та ін.); гнучкість і здатність до адаптації (Р. Стокділл та ін.); товариськість, самовладання (О. Тихомирова); емпатія, стресостійкість, моральність, доброта (Т. Вежевич, Р. Сопівник та ін.); примирення, синергізм цивілізаційних прадигм (А. Косінова); ненасильницький характер стосунків, допомога іншим (Н. Мараховська, Л. Столяренко та ін.).

Спроба переосмислення у 2000 р. теоріїздібностей колективом авторів (С. Заккаро, М. Коннелі, М. Мамфорд, М. Маркс та ін.) утвердила конкретизацію певних навичок, притаманних успішним лідерам, серед яких також було виокремлено: здатність до соціальної адаптації (як складник толерантності), осмислена інновативність, вмотивованість, вміння досягати конкретних цілей, обмежене використання захисних механізмів.

Дослідники сьогодення переконують, що якості лідера необхідно розглядати не ізольовано від соціального контексту, а у зв'язку з ним, i не статично, а динамічно (Романовський, Гура, Книш, Бондаренко, 2017). Нині теорія якостей не відкидається повністю, але стверджується, що лідерство $\epsilon$ продуктом ситуації, тобто під час реалізації лідерських функцій розвиваються необхідні для цього якості. Комплексні дослідження теорії лідерства (Дж. Браун, К. Кейс, Е. Весбур та ін.) стверджують, що лідерство виникає в резуль- таті єдності трьох чинників (особистісних якостей лідера, природи групи та ії членів, а також проблеми, яку група повинна розв'язати), при цьому лідери нової парадигми мають мислити та діяти в координатах і категоріях цінностей, поступаючись особистими інтересами й гординею.

Для обгрунтування лідерських якостей сьогодні дослідники послуговуються здобутками психологів у галузі теорії особистості, виокремлюючи у моделі «великої п'ятірки» ті ж самі якості, що $є$ складниками дефініції «толерантність» або характеризують іiі: товариськість, позитивну енергію, конформізм.

Так, дослідниця І. Дригіна, визначаючи лідерський потенціал, акцентує увагу на внутрішньому наповненні особистості: поєднання внутрішніх потреб, зовнішніх можливостей, особистісних цінностей, які у взаємодії утворюють сприятливі умови для досягнення високого рівня компетентності лідера. Серед компонентів структури лідерського потенціалу вона виокремлює емоційно-екзистенціальний (пов'язаний 3 довірою, емпатією, особистою відповідальністю лідера) (Дригіна, 2003).

На емпатії як необхідній особистісній якості лідера наполягає науковець Р. Сопівник, акцентуючи увагу на тому, що «лідерство виникає в спільноті, то фахівцю емпатія потрібна для ефективної взаємодії з членами спільноти, завоювання симпатії, побудови гармонійних стосунків 3 послідовниками і членами команди, створення атмосфери творчості і взаємодопомоги в колективі»

коГНІтИВний
•усвідомлення ідей
толерантності
•відповідність
принципам
загальнолюдської
моралі
•повага, сприйняття та
розуміння багатого
розмаїття культур
нашого світу, форм
самовиявлення
людської особистості
• законослухняність»,
підпорядкування
законам, традиціям і
звичаям

ЕМОцІЙНО-ЦІННІСНИЙ
•стійкі почуття лідера до
об'єктів, до процесу
толерантної взаємодії з
ними
•емоційно-ціннісне
позитивне ставлення до
людей, інших точок
зору, етнічних питань,
зв'язків, почуттів
•емоційна
врівноваженість,
стійкість до зовнішніх
чинників, позитивне
сприйняття критики
•взаєморозуміння,
компроміс, терпимість,
повага до кожного
члена колективу і
супсільства

ДІяЛЬНІСНО-
коМУНІКАТИВНИЙ
•схильність до певного
типу соціальної
поведінки, основою якої
є розуміння, співпраця
•загальна скерованість
діяльності лідера і
колективу на об'єкти і
явища соціальної
значущості
•взаємодія лідера з
колективом на рівні
діалогу,
співробітництва, опіки
• уміння працювати з
іншим на результат,
попереджати і
розв'язувати конфлікти,
досягати компромісів

Рис. 1. Структура толерантності лідера як його особистісної характеристики 
(Сопівник, 2012 : 244). Він вважає, що емпатія «тісно пов'язана 3 комунікативністю особистості фахівця, адже остання передбачає вміння читати невербальні сигнали, міміку, жести, враховувати при спілкуванні інтонацію, зітхання, тональність і тембр голосу, позу співрозмовника. Усе це дає можливість майбутньому фахівцю як лідеру враховувати зміни, що відбуваються в свідомості та емоційному стані людей, які його оточують» (Сопівник, 2012 : 245).

Спираючись на дослідження науковців (Н. Асташова, I. Дригіна, Н. Мараховська, I. Савицька, Р. Сопівник, О. Тихомирова та ін.), можемо визначити структуру толерантності лідера як його особистісної характеристики, що поєднує три взаємопов'язаних складники: когнітивний, емоційно-ціннісний, діяльнісно-комунікативний (рис. 1).

Відповідно, на основі аналізу психологопедагогічної літератури та власних узагальнень ми виокремили визначення: толерантність викладача закладу вищої освіти як особистісна лідерська якість - це комплексна (інтегрована) характеристика (якість), що цілеспрямовано формується у процесі професійної підготовки й самовиховання особистості, передбачає високий рівень сформованості професійних компетентностей i моральних принципів; здатність бачити в іншому повноцінну гідну особистість незалежно від політичної, релігійної переконаності, національності, рівня освіти, соціального та матеріального статусу тощо; відмову від претензій на власно непогрішність і винятковість; здатність до критичного ставлення до себе й до іншого для подальшого особистісного вдосконалення. Толерантність як вияв лідерської позиції викладача вищої школи складається 3 когнітивного (теоретичне знання основ толерантності, полікультурний світогляд і критичне мислення), емоційно-ціннісного (особистісна толерантна позиція, створення позитивного емоційного насичення освітнього процесу, усвідомлення самоцінності кожної особистості в різноманітних іiі проявах), діяльнісно-комунікативного (здатність виявляти та культивувати толерантну позицію у соціумі, реалізовувати педагогіку партнерства, аналізувати власну діяльність) компонентів.

Висновки. Отже, толерантність викладача закладу вищої освіти як його особистісна лідерська якість є принципом (комплексом принципів) та якістю, сформованими внаслідок впровадження цього принципу. Набуття цих якостей проходить через рівні терпимості, поваги та розуміння. Толерантність викладача проявляється в реальних умовах, що забезпечують атмосферу ненасильства, безпечності, суб'єкт-суб'єктних взаємин, демократичного стилю педагогічного управління, психолого-педагогічної підтримки на основі довіри, поваги та толерантного ставлення (толерантне середовище), при усвідомленні педагогом соціальної, професійної та індивідуальної цінності толерантності (толерантність педагога).

\section{СПИСОК ВИКОРИСТАНИХ ДЖЕРЕЛ}

1. Алфімов Д.В. Зміст феномену «лідерські якості особистості». Педагогіка формування творчої особистості у вищій $і$ загальноосвітній школах : зб. наук. пр. Запоріжжя : Класич. приват. ун-т. 2010. Вип. 11 (64). С. 44-51.

2. Братченко С.Л. Психологические основания исследования толерантности в образовании. Педагогика развития : ключевые компетентности и их становление. Красноярск, 2003. С. 104-117.

3. Васянович Г.П. Професійні якості майбутнього фахівця: науково-методологічні критерії визначення і класифікації. Педагогіка і психологія професійної освіти. 2013. № 3. С. 9-33.

4. Дрыгина И.В. Активизация лидерского потенциала личности студента в образовательном процессе вуза : автореф. дис. ... канд. пед. наук : 13.00.01. Красноярск, 2003. 20 с.

5. Ковальчук В.І. Проблеми управлінського лідерства в професійно-технічній освіті. Вісн. післядиплом. освіти : зб. наук. пр. Київ : Геопринт, 2009. Вип. 11, Ч. 1. С. 101-111. $311 \mathrm{c}$.

6. Кузьмінський А.І., Омеляненко В. Л. Педагогіка у запитаннях і відповідях : навч. посіб. Київ : Знання, 2006.

7. Ляпунова В.А. Функції толерантності як соціально значущої цінності. Педагогічні науки. 2016. Вип. LXIX. T. 3. C. 119-122.

8. Молчанова А.О. Толерантність як ціннісна основа професійної діяльності педагога : посібник. Київ : Інститут педагогічної освіти і освіти дорослих НАПН України, 2013. 188 с.

9. Романовський О., Гура Т., Книш А., Бондаренко В. Теорія і практика формування лідера : навч. посіб. Харків, 2017. $100 \mathrm{c}$.

10. Сопівник Р.В. Виховання лідерських якостей студентів аграрних вищих навчальних закладів : монографія. Київ : «ЦП «Компринт», 2012. 514 с.

11. Department for Education and Skills. Teacher Training Agency. Qualifying to Teach : Professional Standarts for Qualified Teacher Status and Requirements for Initial Teacher Training. London : DFES, 2002. 20 p. 


\section{REFERENCES}

1. Alfimov D. V. (2010) Zmist fenomenu «liderski yakosti osobystosti» [The content of the phenomenon «leadership qualities of the individual»]. Pedahohika formuvannia tvorchoi osobystosti u vyshchii i zahalnoosvitnii shkolakh: zb. nauk. pr. Zaporizhzhia : Klasych. pryvat. un-t. Vyp. 11 (64). S. 44-51. [in Ukrainian].

2. Bratchenko S. L. (2003) Psykholohycheskye osnovanyia yssledovanyia tolerantnosty v obrazovanyy [Psychological foundations of the study of tolerance in education]. Pedahohyka razvytyia: kliuchevye kompetentnosty y ykh stanovlenye. Krasnoiarsk, S. 104-117. [in Russian].

3. Vasianovych H. P. (2013) Profesiini yakosti maibutnoho fakhivtsia: naukovo-metodolohichni kryterii vyznachennia i klasyfikatsii [Professional qualities of the future specialist: scientific and methodological criteria for definition and classification]. Pedahohika i psykholohiia profesiinoi osvity. № 3. S. 9-33. [in Ukrainian].

4. Dryhyna Y. V. (2003) Aktyvyzatsyia lyderskoho potentsyala lychnosty studenta v obrazovatelnom protsesse vuza [Activation of the leadership potential of the student's personality in the educational process of the university] : avtoref. dys. ... kand. ped. nauk : 13.00.01. Krasnoiarsk, 20 s. [in Russian].

5. Kovalchuk V. I. (2009) Problemy upravlinskoho liderstva v profesiino-tekhnichnii osviti [Problems of managerial leadership in vocational education]. Visn. pisliadyplom. osvity : zb. nauk. prats. Kyiv. : Heoprynt, Vyp. 11, Ch. 1. S. $101-111$. [in Ukrainian].

6. Kuzminskyi A. I., Omelianenko V. L. (2006) Pedahohika u zapytanniakh i vidpovidiakh : navch. posib. [Pedagogy in questions and answers : a textbook]. Kyiv : Znannia, 311 s. [in Ukrainian].

7. Liapunova V. A. (2016) Funktsii tolerantnosti yak sotsialno znachushchoi tsinnosti [Functions of tolerance as a socially significant value]. Pedahohichni nauky. Vyp. LXIX. T. 3. S. 119-122. [in Ukrainian].

8. Molchanova A.O. (2013) Tolerantnist yak tsinnisna osnova profesiinoi diialnosti pedahoha : posibnyk [Tolerance as a value basis of a teacher's professional activity: a manual]. Kyiv : Instytut pedahohichnoi osvity i osvity doroslykh NAPN Ukrainy, 188 s. [in Ukrainian].

9. Romanovskyi O., Hura T., Knysh A., Bondarenko V. (2017) Teoriia i praktyka formuvannia lidera : navch. posib. [Theory and practice of leadership formation : a textbook].. Kharkiv, $100 \mathrm{~s}$. [in Ukrainian].

10. Sopivnyk R. V. (2012) Vykhovannia liderskykh yakostei studentiv ahrarnykh vyshchykh navchalnykh zakladiv: monohrafiia [Education of leadership qualities of students of agrarian higher educational institutions : monograph]. Kyiv : «TsP «Komprynt», 514 s. [in Ukrainian].

11. Department for Education and Skills (2002). Teacher Training Agency. Qualifying to Teach : Professional Standarts for Qualified Teacher Status and Requirements for Initial Teacher Training. London : DFES, 20 p. [in English]. 